\title{
Being similar: other-identification during fieldwork
}

\author{
By Olumide Abimbola (Max Planck Institute for Social Anthropology)
}

The paper discusses instances of other-identification when the other is similar to the self, and when difference is brought out by the similar. In a situation that is explicitly legal, but whose legality is predicated on a form of illegality, conducting fieldwork might be a bit challenging. The fact that the fieldworker is a native of sorts helps overcome some difficulties, while at the same time throwing up others. This paper discusses some forms of such identifications and difficulties, and the constant negotiation that is present in the identification process.

\section{The setting}

Cotonou's port, and its bustling market, makes it the commercial capital of Benin. In many ways, the market is the nerve of the city. Benin has been described as an entrepôt economy, and the Cotonou market is a hub for transborder trade between Benin and Nigeria (Galtier and Tassou 1998, Igue and Soule 1992, Igue 1976). I probably should add that most of the goods that leave Benin for Nigeria leave informally; in other words, this kind of trade is what the state - in this particular case the Nigerian state - would categorise as illegal. Different categories of goods are imported to Benin to be re-exported into Nigeria. There are those goods that have relatively high import duties in Nigeria. A good example of this is rice. A Nigerian newspaper reported in 2007 that the import duty on rice in Nigeria was 100 percent, while the import duty on rice in Benin was 38 percent (Alli 2007). During the same year, the association of rice traders in Nigeria estimated that about 2,000 tonnes of rice was re-exported to Nigeria from Benin daily. Another newspaper reported that rice merchants ship 10 percent of their cargo into Nigerian ports, while the remaining 90 percent is shipped into Benin, to be re-exported into Nigeria (Isakpa 2007). Then there are those goods that are expressly prohibited by the Nigerian state, and so their importation through Nigeria's waterways is almost impossible. Examples of goods in this category are used cars that are older than eight years, finished textile products and used clothing. These goods are imported into Benin and traded in the Cotonou market. In the strictest sense, the trade in Benin is legal, but the knowledge that most of the goods that are exchanged in the used clothing section of the market leaves for Nigeria, and the full awareness that these goods are taken into Nigeria illegally, form part of the context in which my fieldwork was carried out.

The main site of most of the happenings in this paper was the used clothing market where I conducted an ethnographic fieldwork among the traders. I was interested in understanding the social life of the used clothing traders, and their deployment of networks that often stretched from Nigeria through Benin to the United States of America, the United Kingdom and other parts of Europe. The main market in Cotonou is called the Dantokpa market, and the section of the market in which used clothing is found is Missebo. Most of the used clothing importers in Benin are Nigerians of Igbo 
extraction, and most of their customers are Nigerian traders who come to buy the goods from Nigeria. Many Beninese refer to Missebo as that part of the market that belongs to the Igbo.

This paper, however, is not about the trade in used clothing or transborder trade, although the larger research project is. This paper is a reflection on my experiences of other-identification during fieldwork. I am a Nigerian, based at an academic institution in Germany, who carried out fieldwork among mostly Nigerian traders in Benin. The next section presents snatches of the different forms of identification - I refer to them as cases - and the contestations that often went along with the identity relations between the traders and me. A concluding part briefly discusses these processes of identification and highlights some of the nuances of the dissimilarities and similarities that may arise in such situations where the fieldworker is a native of sorts from the word go and yet an outsider on account of several facts arising from his biography and his activities in the field. The cases presented below exemplify the different forms of identification that were played out during the period of my fieldwork.

\section{Introducing the cases}

I decided to interview Chijioke, one particular used clothing importer, partly because he is an outlier in the trade in a particular area of Missebo. For one, he is not from the same village as the other people on the street, he is not even from the same Nigerian federal state (he is from Anambra state, and most of the traders are from Abia state); and he imports his goods from Belgium, while the others mostly import theirs from the United Kingdom. A combination of these factors makes Chijioke interesting. My friends on the street had told me that he would not have much to tell me about the history of the trade since he arrived in the market not so long ago, and that he probably would not have much to say on the organisation of the market either, since he rarely relates with other people in the market. In fact, most of his buyers come from Nigeria, an anomaly in itself, since the traders who come from Nigeria normally buy their goods from Cotonou-based retailers who buy from the importers. The trade is organised in such a way that those who come to buy from Nigeria rarely buy directly from the importers. They normally do not buy in such large quantities as to make it worth the while of the importer to sell directly to them and risk alienating his customers, the retailers, because then he would be in direct competition with them. This would, in part, account for why the people on the street do not have much to do with Chijioke. And apart from that, he is a successful used clothing importer, who sometimes imports up to two 40-feet containers of the articles per week - an average importer imports about two 40-feet containers of used clothing per month - but who is not from the same village as those who dominate the second-hand clothing business in Cotonou.

Chijioke is normally not in his shop, but I had been told that whenever I saw a Honda SUV with a Nigerian number plate in front of his shop I could go in and ask for him. On this particular Monday afternoon, after having interviewed someone who told me about the workings of the trade, and an old man who came to Cotonou in 1972 and has since then been trading in used clothing, I came to "our street" to catch my breath before deciding whether that was already enough for the day. (I was based in a store that deserves its own ethnography because of the peculiar mix of people who lay claim to the place. When talking to other traders on the street - a street in Missebo - I, 
like every other person on the street, refer to it as "our street".) As I got into the street I looked at the front of Chijioke's shop and saw a metallic-blue Honda SUV with a Nigerian number plate. I thought that it most likely belonged to Chijioke. I asked someone in a shop nearby and he confirmed that Chijioke was in his shop. I walked into the shop and met his "boy" whom I asked whether I could see his "master". (Unpaid apprentices among the Igbo are normally referred to as "boys", while the masters are simply called "master". For more on this see Agozino and Anyanike [2007] and Chukwuezi [2001].) He went into a section of the shop that was partitioned off as a private office, opened the door, looked in and spoke with Chijioke. I could not hear what he said, and neither could I hear the reply Chijioke gave him, but he came back to tell me that his master told him to tell me that he was really busy and could not meet with me. I was surprised and a little angry: that was about the first time anybody had refused to meet with me without even asking what I wanted. I walked out of the shop and went to the next shop, where I had friends, and told one of them about what had happened. He was equally surprised, and he asked me whether anyone had behaved that way to me before. I replied that no one had. I decided that I had had enough of that part of the market, and that it was time I went to another area where I had two friends waiting for me, but on second thoughts I decided to leave my complimentary card with Chijioke's boy, telling him to give it to his master, and to tell him that I would come back some other time. I then left.

When I got to my friends they too were surprised that anyone would deny me audience the way Chijioke did, but one of them, Ben, was quick to point out to me that Chijioke had probably been seeing me around, and had been wondering who I was. I replied that I doubted whether Chijioke actually knew me, since he was rarely in his store, and it was his boy who took care of the day-to-day running of things. I also said that I had been in the market for about seven months, that people were already used to me, and that it would be strange if anyone should find me strange at that stage. I drew his attention to my relationship with the people of our store. The store was an "office" - a "loading" point - for drivers who commute between Lagos and Cotonou; it is at the same time a used clothing store. I probably do not need to point out the importance of such a place for an anthropologist whose fieldwork is partly on the transborder trade in used clothing, and the importance of having been accepted as one of the "inhabitants" of the store. I reminded Ben about my acceptance, and how I sometimes was the one who opened the store, and who stayed there while nobody else was there. This, I told him, showed that I was fully integrated, one of the traders, a person who was trusted enough to be left alone in the store.

He looked at my face, smiling, and said: "Oh, just imagine what a person who walks into our street would think of a bespectacled, backpack-carrying person in a shop. Yes, you dress down, you relate well with the people, you are friendly with them, but the fact still remains that you are not one of them." He went further to remind me of what we had discussed earlier: people sometimes feel a bit intimidated when they meet a young Nigerian doctoral candidate who is based in an institute in Germany, especially when they themselves have not had any university education. He even thought that dropping my complimentary card could have destroyed any possibility of meeting with Chijioke, because if he did not know that I was a doctoral candidate before then my card was sure to give him information to that effect.

At that moment it struck me that if anything, my anger at Chijioke's treatment was a reflection of how many relationships I had already established in the market. And even more, it struck me that my anger was partly a result of the arrogance of being 
"one of them", of being a Nigerian who had a lot of shared frames of reference with other Nigerians, and who could relate to many things along with them. At that point I thought back to how I was perceived by the traders, the categorisations that were applied to me, some with attendant difficulties, and some with their advantages. Some of their perceptions of me were totally against any way I would self-identify, while others were only partial views, views that I might agree with but that would not be comprehensive enough for me to accept. In this short paper, I reflect on some of the ways I was labelled, and discuss them in the context in which the labels were applied to me. Of course, I should add that these labels are just a few of the ones I came to know about.

\section{Case 1: the spectacle-wearing, backpack-carrying spy}

As I wrote earlier, the Nigerian traders in the market are mostly of Igbo extraction, save for a few Nigerian Yoruba moneychangers. In my second month in the market I tried to interview Chief $\mathrm{O}$, an Igbo auto spare parts trader from Anambra State, who arrived in the market in 1971, shortly after the Nigerian civil war. (The 1967-1970 war was between the predominantly Igbo-speaking eastern region of Biafra and the Nigerian federal government; see Stremlau 1977.) I was introduced to him by another Anambra State citizen, who was introduced to me by his friend, a second-hand clothing trader. I thought that it would make for a richer understanding of the motivation for the migration of Igbo shortly after the war if I interviewed people who traded in other goods apart from used clothing. In addition to this, my friend, Eke, who introduced me to Chief O, had told me some of the stories Chief $\mathrm{O}$ told him of the situation in Cotonou when they first arrived. I thought that it would be invaluable to hear those stories from the concerned party himself. I had earlier told Chief $\mathrm{O}$ that I would like to interview him and although he did not indicate his interest, he did not decline. I took his silence for acquiescence and one afternoon I asked Eke's boy to take me to his shop.

We arrived at his shop and I told him that I was there for the interview I had told him about. He looked around a bit and said, not looking at me, that he was not qualified to talk about the history of other people. I replied that I was only interested in the way he experienced the market, and that there was nothing about "other people's history" in that. He replied that he really could not tell about the history, but that there was someone else, a Nigerian from my own ethnic group, who could tell me about the history of the market. Before I could protest he sent one of his boys to call Akeem, a Nigerian Yoruba moneychanger. Akeem too was rather surprised that Chief O invited him to tell me about the history of the market. He reminded the Chief that he had been in the market for only about 13 years, while the chief had been there for over 30 years. Chief O replied that I was his (Akeem's) brother, since we were both Yoruba, and that Akeem would certainly be able to help me better than he ever could. I thought about raising an objection but I decided that I would leave that battle for Eke to fight on my behalf. I asked Akeem a couple of questions before leaving.

When I got back to Eke's shop I told him the story and he laughed. He told me that he had suspected that something like that could happen, but he wanted me to first make a try anyway. That was when he explained to me that Chief $\mathrm{O}$ had told him to be careful around me because I could be a spy sent by the Yoruba nationalist organisation, O'odua People's Congress (OPC), to study the economic activities of the Igbo in order for the organisation to subvert them. Eke said that he had tried to explain to 
Chief O that I was only a doctoral student on fieldwork, and that I did not even live in Nigeria, but Chief $\mathrm{O}$ refused to believe him. How else could one explain the motivations of a young Yoruba man in a market, a man asking about the economic activities of the Igbo? Nothing explains it better than espionage. Of course, there are other ways he could have seen it, but that was the most convenient for him. His refusal to be interviewed by me was not because a Nigerian Yoruba would tell a different story from an Igbo, but because he did not feel comfortable talking to me. I heard a number of things from people in the market, and from many indications, people still felt that the south-eastern part of Nigeria was marginalised, and that the Igbo were not getting a fair deal from the Nigerian government; therefore it was only prudent to be careful in speaking with a Yoruba who was asking questions about Igbo economic activities, more so when answering the questions would lead them to talk about the civil war. (For more about the civil war and the relationship between the Hausa, the Igbo and the Yoruba, the three largest ethnic groups in Nigeria, see Salamone [1997].)

This is the sort of reception I also got from another elderly man who arrived in Cotonou before the war. I was directed to him by someone in the office of the head of the Nigerian community in Cotonou, with promises that he would be able to help me understand the history of the trade in used clothing. I got to his house with my friend Ben, who did the introduction. After the first few minutes the elderly man turned to me and asked, in Igbo, why I did not introduce myself. I replied that I was not Igbo, and that my command of the Igbo language was hopelessly limited. He asked where I came from and I replied that I was a Nigerian, a Yoruba. He paused for a while. Then he replied that he would not be able to grant me an interview on that day, but that I should come to see him the following day in the morning, at about 10 o'clock. When Ben and I were walking back I asked him why it was that the old men were the ones who were the least willing to grant interviews. He replied that many of them could be scared that I was a spy, and that "the Biafran thing is still in their heads". We returned the following morning and he granted us a full interview. My friend and I discussed the reason he finally granted the interview and we concluded that he might have done it because he had thought about it and concluded that I was not a threat.

I witnessed another version of the spy identity when I tried to interview the head of the Nigerian community in Cotonou. I had planned to interview him in his capacity as a used clothing importer, and as the head of the Nigerian community. Before going to the office, Ben told me that I should not go with my glasses or my backpack because the head of the Nigerian community, in Ben's words, had not gone to school, and that he might feel intimidated by me if I appeared like a person who had read too much. I did as Ben advised, and the first time I called at his shop I was told to talk to his personal assistant. The personal assistant grilled me for a couple of minutes before telling me to go and write a formal letter of request to the president of the Nigerian community, telling him what I wanted from him, and the questions I would like to pose to him. I did so and brought the letter the following day. The personal assistant read the letter and then proceeded to the questions. He read them and smiled. He looked up at me and asked: "How do you think the president can answer these questions?" I asked him which ones and he said numbers three to six. I immediately understood what he meant. Between questions about the Nigerian association, I had sandwiched in four questions about the second-hand clothing trade and about the identity of the head of the Nigerian community, questions that I hoped would help prepare the grounds for a rich discussion. Those were the questions that the personal 
assistant was curious about. He went on to inform me that the president could not possibly answer those questions, and neither could he, the personal assistant, since I was not interviewing a used clothing dealer but the head of the Nigerian community in Cotonou. I launched into a long speech about persons and identities. He must have been bored stiff because he, the personal assistant, eventually agreed to answer the questions.

However, I only understood what had happened when I arrived at Eke's office. A couple of years ago, the speaker of the Nigerian House of Representative visited Cotonou, and during a reception he accused the traders of being culpable for the failure of many Nigerian industries. He told them that the Nigerian traders in Cotonou import goods that are banned in Nigeria into Cotonou to sell to Nigerians who smuggle them into the country. The personal assistant was scared that I could be a spy for the Nigerian government, a spy who had come to investigate those trading in products that are banned in Nigeria and who would report back to the government. It would not look too good if it was found that the head of the Nigerian community himself was involved in the contraband trade, although everybody knew it anyway. It was not until my long speech that he concluded that I did not work for the Nigerian government.

\section{Case 2: the German citizen}

One of the first things I learnt in Cotonou was that many of the young men were looking for means to emigrate to Europe. In fact, many people came to Cotonou just to do that. Therefore, when I told them that I was a doctoral candidate at a German institute, and that yes, I was living there during the period of my studies, the second part of the statement somehow got lost and I simply became a German citizen. I repeatedly corrected this impression, but many people told me that it was a false sense of modesty, and that it was alright to own up to my true identity. Of course, there were people who understood that I was simply a student in Germany, but in most cases it was assumed that I denied my German citizenship so that I would not receive too many requests for help with emigration.

One particular case in which this identity proved to be of advantage was when I wanted to seek an internship in the shop of some young men who import used clothing from the United Kingdom. I had earlier talked to one of the directors, Eme, and he said that I would have to talk to the others since he came to join the business only recently. The others had a stronger say in deciding whether I would be allowed to stay in their shop or not. I arrived at the shop one afternoon and Eme introduced me to the person who was effectively the manager of the business. He introduced me as a German citizen doing research on the used clothing business in Benin. He also added that since I was a German citizen I might be able to help the company in establishing contact with German used clothing exporters, and that if possible I might be able to help get them invitations to Germany. Of course, I understood that the unsaid word was that I might be able to help some of the boys in the shop with migration to Germany. Seeing the look on my face and sensing that I was about to raise objections, Eme quickly asked me to give my complimentary card to the manager, and that he and I could discuss this at greater length the following day. As we left I asked Eme why he introduced me as a German citizen. He replied that if the manager thought that there was something they could gain by helping me gather information it would be easier for him to agree to help me. 
The assumption that I was a German citizen also facilitated discussions with traders who had lived in Europe at some point. Even they did not believe it when I told them that I was not a German citizen. How else could one explain that I was going "back" to Germany after my year of fieldwork with them? Or that I would not have to go and apply for a visa when I was going "back"? My explanations that I had a residence permit with validity that extended beyond the time I would be returning to Germany at best only made someone ask whether I had recently become married to a German lady. He too had lived in Germany for a while and was very well acquainted with German immigration laws. These traders felt surer of things when a female German colleague who was doing research on Chinese migrant traders in Cotonou came with me to the used clothing market. They immediately assumed that she was my wife who had come to visit me from Germany.

\section{Case 3: a trader on a feasibility study}

Closely related to the assumption that I was a German citizen was the one that I was a trader who lived in Europe but was in Cotonou to learn about the trade before getting involved in it myself. In the early period of my fieldwork I was warned not to let the traders get the impression that I was learning the trade or they would think I wanted to steal their business from them. This was a situation I had thought about before going on fieldwork, and in a sense I was prepared for it. Nobody ever actually told me that they thought I would steal their business from them, but this of course does not mean that there were not people who thought about it, or probably even talked about it. What was evident was that the thought that I was trying to get involved in the business - not to steal their business, which, in effect, would mean stealing their contacts - actually increased my chances of establishing rapport with some of the younger traders who were at the bottom rung of the trade and who were hoping to get someone they might represent in Cotonou, someone who would send goods for them to sell from Europe. But no analysis of my relationship with the people at the bottom rung of the ladder should ever overlook the fact that most of them were not people who had business contacts that I could steal, if I was looking for that. Many people, including those higher up in the business, opened up rather nicely to me, teaching me the intricacies of the trade, and telling me that yes, it is possible to make millions in this trade within a year. And please, could I send goods to their shop from Germany so that we could create a good team together?

One of those who held this assumption was one of the persons who assumed that I had just recently become married to a German lady and so did not yet have a permanent residence permit. We had been talking for a while and I was really happy to find someone who was ready to tell me almost anything I needed to know about the trade. I understood that he did not believe my explanation about how I was on fieldwork only to study the trade in used clothing when he started explaining how to go about setting up a warehouse in Germany, and how to get people to buy the goods I sourced from Germany. All of this he explained with specific reference to me. I did not want to break the flow of the discussion, so I did not correct his impression right there and then. But at some point he asked what kind of residence permit I had, trying to gauge whether I would be allowed to start up a company in Germany with it. Before I left his shop I explained to him, again, that I was a research student, and that I did not have any interest in joining the trade. As I told him this he smiled and told me that I could come to him any time I needed someone to talk to. During our subsequent 
discussions I managed to convince him that I was just a doctoral student, and that I did not plan to join the trade in used clothing.

\section{Identification: personal reflections}

Someone recently asked me how I managed to deal with the issue of being Yoruba amongst Igbo traders. The question came from a person who was not familiar with anthropology, and who did not understand that ethnographic fieldwork was originally conceived as an exercise with the unfamiliar. To her understanding, any difference posed difficulties, and the difference between being Igbo and being Yoruba was enough to be a great source of difficulty. I did not probe the question itself, but one could also assume that the difference she perceived was not the difference of the labels themselves, but the difference of the conceptions of Nigerian stereotypes of the two ethnic groups. The Igbo are taken to be people who are born with a gene for trade and another for profit-making, and the Yoruba are said to only go to school and look forward to a safe, salaried life. I replied to my friend that my reception was probably best facilitated by the fact that I came directly from Germany, and that I could not help wondering how I would have been received if I had come to the field from a Nigerian university.

While there were obvious differences between a Germany-based Nigerian doctoral candidate and a Benin-based Nigerian trader, there were also similarities. The similarities laid the ground for acceptance, but other dynamics obviously contributed to its actualisation, such that one cannot easily say what really made it easy for the traders to accept me. For one, the expectation that I might "bring business" to them did indeed facilitate my reception, just like the assumption that I might be able to help with migration to Europe. One interesting thing to note, however, is that many people told me that many traders agreed to talk to me about their business precisely because I am not Igbo but Yoruba. An Igbo man could have come to learn about their business, get to know their suppliers and "steal" business from them. A Yoruba, on the other hand, is not perceived to be that interested in business; all he wants is to study, get his degrees and get a comfortable salaried job. That was one advantage of being a Yoruba during my fieldwork.

I am now back in Germany to write up my dissertation, the text that is the report of my experience in Cotonou, and while I do not lay claims to any attempt to produce what Marilyn Strathern has described as auto-anthropology - "anthropology [that] is carried out in the social context which produced it" (Strathern 1987:17) - I do present the people; and I present them in ways that I hope are close enough to how they would present themselves, or at least to how they would have me present them. Strathern goes on to explain the extent to which the generation and distribution of autoanthropology is limited, partly because the account that is produced would generally differ from the self-presentation and self-accounts of the people who are presented. In the above cases, the wheel comes full circle: the different understandings that the traders had of me, the researcher, were presentations that I constantly disagreed with and contested. In many cases the contestation was successful, but on some occasions it was not. But these back and forth processes of identification, the business of labelling and the contestations of labels, happened within a context, and, as the cases show, these processes were vital to the emergence or otherwise of a relationship between differently positioned traders and me, the researcher. 
In their discussion of identification, Brubaker and Cooper (2000:14) identify different levels and modes of identification: "How one identifies oneself - and how one is identified by others - may vary greatly from context to context; self- and otheridentification are fundamentally situational and contextual." These two forms of identification were the ones that were constantly debated during the time of my fieldwork. I had the opportunity to either verbally reject the categories of otheridentification, as I did on many occasions, or to act out the rejection, as I did on the occasion when I reeled off a speech to the personal assistant of the head of the Nigerian community in Cotonou. There were also cases when I had no opportunity to do either of these, either because I was unaware that many thought of me in those terms or because I was caught unawares when a particular act of other-identification was performed on me. However, these identifications went on under the assumption that I was a kind of insider, someone with a shared commonality. I was taken to be one of them, a Nigerian, who was together with them in a different country, even if that country was only a few kilometres away from our home country. There were differences between us, but our shared similarities were what brought out the differences. In other words, the familiar was what drew out the unfamiliar, and the similarity the difference (cf. Schlee 2002, 2004).

One shared commonality we had was co-belonging in the same nation state, and the presence of markers to show that co-belongingness. My name is a Yoruba name, and even when Chief O told me to talk to Akeem, another Yoruba who was my "brother", it still happened within a context in which we all acknowledged our shared nationality. This comes up again in the description of me as a spy for the Nigerian government, or even for the Yoruba nationalist organisation. But an even more interesting case was when I was described as a German citizen, and when my assumed German citizenship was seen as a resource that could be exploited for the benefit of fellow Nigerians. Therefore, I was not someone who had to pull a story out of thin air to be taken, on one level, as "one of them"; the Nigerian state had already done that for me, not just by giving us the same nationality that is often expressed in passports and other documents, but by giving us markers that formed the basis, on another level, of a shared commonality. I could therefore speak to them in English, and more importantly in Nigerian Pidgin English. The difference, I repeat, was in the familiar, and the unfamiliar in the similar.

\section{References}

Agozino, B. and I. Anyanike. 2007. IMU AHIA: Traditional Igbo business school and global commerce culture. Dialectical Anthropology 31(1), 233-252.

Alli, Franklin. 2007. Smuggling threatens local rice industry - traders. Vanguard Newspapers, May 31. Lagos.

Brubaker, R. and F. Cooper. 2000. Beyond "identity". Theory and Society 29, 1-47.

Chukwuezi, B. 2001. Through thick and thin: Igbo rural-urban circularity, identity and investment. Journal of Contemporary African Studies 19(1), 55-66.

Galtier, F. and Z. Tassou. 1998. La réexportation: Vice ou vertu? Le commerce du Bénin vers le Nigeria. Autrepart 6, 123-143.

Igue, J. and B. Soule. 1992. L'Etat entrepôt au Bénin. Commerce informel ou solution à la crise. Paris: Editions Kartala. 
Igue, Ogunsola John. 1976. Evolution du commerce clandestin entre le Dahomey et le Nigeria depuis la guerre du "Biafra". Canadian Journal of African Studies / Revue Canadienne des Etudes Africaines 10(2), 235-257.

Isakpa, Phillip. 2007. Nigeria loses N25bn to cross-border rice smuggling. This Day Newspapers, July 8. Lagos.

Salamone, F.A. 1997. Ethnicity and Nigeria since the end of the civil war. Dialectical Anthropology 22(3-4), 303-333.

Schlee, G. 2002. Imagined differences: Hatred and the construction of identity. Münster: Lit Verlag.

--------. 2004. Taking sides and constructing identities: Reflections on conflict theory. Journal of the Royal Anthropological Institute 10(1), 135-156.

Strathern, Marilyn. 1987. The limits of auto-anthropology. In Anthropology at home, ed. A. Jackson, 16-37. London: Tavistock Publications.

Stremlau, John J. 1977. The international politics of the Nigerian civil war, 19671970. Princeton: Princeton University Press.

\section{About the author}

Olumide Abimbola is currently writing his doctoral dissertation on Igbo used clothing trade networks at the Max Planck Institute for Social Anthropology in Halle/Saale, Germany. His general academic interests include informal trade, the international trade in used clothing, Igbo trade networks, and regional integration. He can be reached at abimbola@eth.mpg.de 